\title{
Designing Marketing Strategy Based on Value from Clothing- producing Companies using the AHP and Delphi Methods
}

\author{
Hasrini Sari *, Diningtyas Aulia Nurhadi \\ Industrial and Engineering Management, Institut Teknologi Bandung, Indonesia \\ Jl. Ganesha 10, Bandung 40132, Indonesia \\ *Corresponding author: hasrinis@gmail.com
}

\section{ARTICLE INFO}

\section{Article history}

Received February 17, 2019

Revised April 18, 2019

Accepted July 1, 2019

Available Online August 31, 2019

Keywords

Marketing strategy

Positioning

Segmenting

Targeting

Value

\begin{abstract}
Organizations design some strategies to win the competition. This paper discusses the design of market strategies to achieve harmony between value-based segmentation and marketing mix. The strategy's implementation starts with segmentation, targeting, and positioning. The clothing company ("M") was selected as a research object. Identification of market segments using cluster analysis while determine the target market using the AHP and Delphi method. Besides, Bull's eye research was used for product positioning. The results show that "M" customers are classified into two groups, referred Big Spenders and Discount Finders. Big Spender was selected as the primary target market with a focus on size and durability. The marketing strategy focuses on Instagram and Facebook. As a result, the ads developed prototypes have proven to be better.
\end{abstract}

This is an open-access article under the CC-BY-SA license.

\section{Introduction}

Competition-winning strategies are not enough to rely on the production strategy. The company must create the right marketing plan for the product. This approach aims to meet the needs of the consumer. Value is a concept that uses the needs of the customer to develop strategies. Values are becoming a central theme that can be used as a foundation for creating a competitive strategy. The importance of customer perception is described as a comparison of benefits and costs [1]. The benefits and costs included in this definition are monetary and non-monetary. Therefore, there must be a balance between the value given by the supplier and what the consumer thinks. The key to success, according to the interest perceived by the customer, is to meet the needs of the consumer [2]. Much research has been conducted to explore customer value. Nevertheless, all of them have significant factors or variables that influence the perceived value of the customer. Hong, et al. [2] identify the dimensions of consumer perceived value in a fashion product context. The perceived quality and reputation influence the value of services offered by hospitals [3]. Dimensions of customer value that influence customers in choosing wine are studied in Wiedmann, et al. [4]. A study about the relationship between 
service quality and customer value is presented in Yu, et al. [5]. Previous studies did not discuss the mechanism in depth after the identification of variables. Nevertheless, the interest of the consumer must be the foundation for designing marketing strategies.

Besides, previous studies focus on the relationship between marketing strategy with the outcome. As a result, only a few researchers focus on the process of developing a marketing strategy. Two hundred fifty-seven papers were published from 1999-2017, less than $6 \%$ focus on developing a marketing strategy [6]. Researches on marketing strategy have been carried out in the last five years (2014-2018) in paper form Abiddin, et al. [7] and Robbika and Baroto [8]. The formulation of a marketing strategy based on SWOT analysis without identifying the target market and market position is presented in Abiddin, et al. [7]. The formulation marketing strategy of a service company is described in Robbika and Baroto [8]. This paper discusses designing a marketing strategy to achieve alignment between need-based segmentation with the marketing mix. Three things make this paper different from previous studies. This research encompasses steps from identifying current customer needs. In addition, researchers have sorted it into various groups, identified a target market, and established a positioning and marketing mix strategy. In contrast to this paper, most of the previous studies did not discuss all these steps comprehensively. Some articles discuss how to segment and target the market [911]; product positioning [12, 13], and the effect of a particular positioning strategy [14-16]. Gengler and Mulvey [17] Investigate customer value and use it as the basis for segmenting and positioning the market. The group customers are according to brand preference and price sensitivity. Moreover, they are planning the pre-launch position of certain types of Motorola phones. The latent class model is used to segment the customers. Market position is then developed based on the interpretation of the characteristics of each segment.

Delphi and AHP are used to determine the target market. The two methods are instrumental and have been used in many areas of researches. Bouzon, et al. [18] use the fuzzy Delphi and AHP methods to identify and analyze the barrier factors of reverse logistics in the Brazilian electric-electronics industry. Delbari, et al. [19], in their study, combine the Delphi method and AHP in identifying competitive factors of full-service airlines. In this study, Delphi and AHP are used to determine the importance of segment attractiveness criteria. This paper is carried out in the context of social media. Most of the previous research in this context only considered the effects of individual parts. For example, several studies investigated the effects of messages conveyed in social media marketing [20]; [21]; [22], endorsers [23], and the role of social media in managing a project [24]. On the other hand, this research focuses on designing and testing the proposed strategy on social media.

The "M" company was selected as the object of research. The company is engaged in the convection of women's clothing. Furthermore, the results of the customer and respondent satisfaction surveys provide several suggestions that can be categorized as components of the marketing mix. Investigations revealed that $41.3 \%$ of respondents were "M" customers but not the "M" target market. The current target market is built on a demographic basis. Therefore, the target market should be made before formulating a strategy. The right target market will produce the right strategy to target customers. Besides, it can increase customer satisfaction and increase company profitability. This paper is organized as follows. The first part is the introduction. An explanation of the basic concepts and the research method used in this paper is presented after this. Then, data processing has presented and analyzed, followed by a strategy recommendation as to the research implication. 


\section{Methods}

The research method used in this study is a survey. A survey is an activity done to gather information systematically about the characteristics, beliefs, opinions, and behaviors of many people [25]. This research attempts to find out the characteristics of the customers. Therefore, a survey is a suitable method for this research. The survey method used was a questionnaire.

\subsection{Measurement Instrument Design}

The questionnaire in this research was intended to find out the market segmentation of "M". The segmentation used in this study is needs-based. "M" wants to fulfill customers' needs on clothes that are high quality, affordable, can be bought online and offline. The previous market position is "best quality at an affordable price." Market positioning and marketing mix approach " $\mathrm{M}$ " was measured by asking consumers "M" through a questionnaire. There were three sections to the questionnaire. The first part is about the profile of the consumer. The second part is information on the recognition of customer needs. The final part is the assessment of the "M" marketing mix approach. The responses are provided in the second and third parts of the questionnaire in several choices with Five Likert Scales. That question in the questionnaire has been adapted from previous studies that have been modified and translated. Previous studies and items adopted are presented in Table 1.

Table 1. Constructs and indicators

\begin{tabular}{ccc}
\hline Construct & Variable & Reference \\
\hline Quality & Performance & {$[26]$} \\
& Feature & \\
& Reliability & \\
& Conformance & \\
& Durability & \\
& Serviceability & \\
& Aesthetic & \\
& Perceived Quality & {$[27] ;[28]$} \\
Customer needs & Product & {$[29] ;[30]$} \\
Marketing Mix & Promotion & \\
& Price & \\
& Place & \\
\hline
\end{tabular}

The question is translated into Indonesian and then re-translated to ensure that there is no change in meaning. The sampling method used in this research was convenience sampling. The population from this research was "M" customers as the current target market. They were considered a group of people who know well about "M" the marketing mix strategy of "M". Potential customers were omitted because "M" needs to focus first on its current customers. The minimum number of respondents who filled the questionnaire was based on the Green equation [31] (Equation (1)).

Minimum respondents $=50+8 \mathrm{~m}$

$m$ : number of independent variables

In this research, fifteen independent variables consisted of (a) eight variables for product quality measurements, (b) one variable for customer needs, and (c) four variables 
for marketing mix approach purchases. The total number of respondents was 170 people. Nevertheless, it claimed that cluster analysis is not an inferential statistical method. Therefore, the emphasis is more on representation and the importance of the number of samples to be grouped.

\subsection{Questionnaire Distribution and Record}

The questionnaire was distributed as a sample of 30 respondents in Bandung, Indonesia. Results from the questionnaire are used to improve the quality of the questionnaire. Data was tested based on IBM SPSS Statistics 20 in terms of validity and reliability. If the data from the preliminary study have passed the test, the distribution of the questionnaire is to continue. The number of respondents in this study is 178 respondents.

\subsection{Data Processing}

The minimum number of respondents to the collection of data is achieved. Clustering consumers who have the same desires in the context of a market segment. The sorting approach is the study of the grouping. The variable with the smallest number of correlations is used as a cluster variable. The number of clusters is calculated by the shift in heterogeneity using the agglomerative ward process. Besides, the clustering approach used was non-hierarchical k-means as cross-validation validation checks. The algorithm of this technique is based on optimizing the distance between clusters [32]. Moreover, characteristics for each cluster were identified with the cross-tab method. Significant characteristics that distinguish each cluster were identified with Pearson Chi-Square.

The target market was defined based on the segment attractiveness of each cluster. Segment attractiveness was measured using the AHP method with interview input data. The interview was conducted by the researcher using the Delphi method and was conducted in two parts. The first part was the pairwise comparison of each criterion. The second part was the relative measurement of each alternative for each criterion. Experts are asked to rate criteria and sub-criteria based on their significance and to assess each alternative based on sub-criteria. There were three criteria for determining the attractiveness of the section, and there are three sub-criteria for each criterion. The process has been replicated until an agreement has been reached. To test the consistency of the interview input data, the AHP Consistency Test was used. The test was accurate if the accuracy ratio was less than 0.1 [33]. The consistency ratio was calculated by dividing the consistency index with the random index.

An analysis was carried out to determine whether there was a correlation between the target market characteristics and the current market positioning using the Bull eye test. Bull's eye is a technique in which the target is positioned at the center of the circle. Other factors circle the target in a concentric system [34]. The scope of the outer circle is more extensive, broader, and encompasses the inner circle. There was a gap between the target market needs and market positioning. Furthermore, a new market positioning was designed. Moreover, the improvement of the marketing mix strategy was made regarding the result of the one-way ANOVA and ANOVA post hoc test of the average number of variables in the third part of the questionnaire. The improvement was made only to the component(s) with/have an average number below the neutral score (3).

\section{Results and Discussion}

Data are processed and analyzed in three steps. Detailed of each step is described below. 


\subsection{Market Segmentation}

There are 30 samples of data collected then processed through multicollinearity, validity, and reliability tests. Data collection continues to reach 178 . Then, the data is processed using cluster analysis to determine market segmentation and data processing using SPSS. At the initial step, choose the clustering variable and all variables measured by one indicator used as clustering variables. Besides, clustering variables are selected based on several correlations. Selected variables are features, reliability, serviceability, durability, price, online and offline places, ease of care (performance), brand image (reliability), originality design (aesthetics), and product value (quality perception).

The number of clusters identifies using the ward method. The rule for determining cluster numbers is to assess differences in heterogeneity between cluster solutions. If there were a substantial increase between two alternative cluster solutions, the prior alternative could be selected. The calculation for the number of the cluster seen in Table 2 .

Table 2. Number of cluster calculation

\begin{tabular}{ccc}
$\begin{array}{c}\text { The number of } \\
\text { Clusters }\end{array}$ & $\begin{array}{c}\text { Agglomeration } \\
\text { Coefficient Change }\end{array}$ & $\begin{array}{c}\text { The margin of } \\
\text { Coefficient Change }\end{array}$ \\
\hline 5 & 70.805 & $26.95 \%$ \\
4 & 76.048 & $6.89 \%$ \\
3 & 107.371 & $29.17 \%$ \\
2 & 227.290 & $52.76 \%$ \\
1 & - & - \\
\hline
\end{tabular}

Table 2 shows the optimal number of clusters by two segments. It has the essential coefficient and shifts margin among all other qualifying clusters. Changing the factor group is indicative of the homogeneity of a single group. Besides, cluster validation was carried out, and the findings were 22.47 percent. It is between $20 \%-25 \%$, so it is known to have a stable solution [32]. After that, the characteristics for each cluster identified by the method of cross-tab. Significant characteristics differentiate each cluster found by the cross-tab. Differences between the two clusters are known by looking at the value of Pearson Chi-Square. If the significance value was less than 0.05 , there were significant differences between the two clusters for this criterion. It is revealed that the characteristics that differentiate between the two clusters are customer needs, shopping frequency in a year, and the amount of money that is spent at each shopping. Other characteristics are not significantly different for the two clusters. The result from the market segmentation, including the demographic profile of each cluster seen in Table 3.

This study segment the market based on customer needs and behavior. Segmenting customers is the first and essential step of marketing strategy development. According to Yankelovich and Meer [35], segmentation should identify the groups based on customer needs that are worth pursuing by the organization. Queen and Miller [10] also found that segmentation solely based on demographic factors was not sufficient. It is because the resulting segment cannot be used to differentiate the marketing strategy. On the other hand, translate segmentation based on behavior and benefit sought directly into a message delivered to each segment. 
Table 3. Market Segmentation

$\begin{array}{ccc}\text { Criteria } & \text { Cluster } 1 & \text { Cluster } 2 \\ \text { Needs } & \begin{array}{c}\text { Fit size } \\ \text { Affordable price }\end{array} & \begin{array}{c}\text { Fit Size } \\ \text { Durability }\end{array} \\ \begin{array}{c}\text { Shopping frequency } \\ \text { at "M" in a year }\end{array} & 1-2 \text { times } & \text { More than two times } \\ \begin{array}{c}\text { The amount of } \\ \text { money spent on each } \\ \text { shopping at "M" }\end{array} & \text { Not more than IDR } & \text { More than IDR 300,000 } \\ \text { Monthly income } & \text { More than IDR 26,000,000 } & \text { More than IDR 26,000,000 } \\ \text { Age } & 16-57 \text { Year } & \text { 16-59 Year } \\ \text { Cluster Name } & \text { Discount Seeker } & \text { Big Spender }\end{array}$

\subsection{Target Market Determination}

The target market determines the attractiveness of the categories. The market with the highest segment attractiveness is set as the target market. The attractiveness of the categories is compared to the value score of the parameters and the ranking scores of each market segment. These criteria refer to the tree hierarchy in Fig. 1. The definitions for each criterion are shown in Table 4.

Table 4. Criteria and Sub-criteria Definition

\section{Criteria or Subcriteria}

Market Demand [36]

- Market Size [36]

- Growth Rate [36]

- $\quad$ Market Potential [11, 36]

Competition Intensity [36, 37]

- Number of competitors [38]

- Market's barrier to entry [36, 38, 39]

- Product substitutes [36, 40]

Market Access [36]

- Familiarity $[36,41]$

- Channel Access [36]

- Company fit [36]
Definition

Number of customers

The number of demands in the current period

Increment of demand over time

The estimated demand in the future

The company's effects on its competitors in the existing market

The number of companies offering the same product in the existing market

The easiness of other companies to enter the existing market

The number of replacement products offered by other companies

Facilities and infrastructure owned by the company in reaching its customers

The level of company's understanding of the needs and desires of its customers

Media owned by the company in reaching its customers The company's ability to meet customer demands under the company's owned resources 


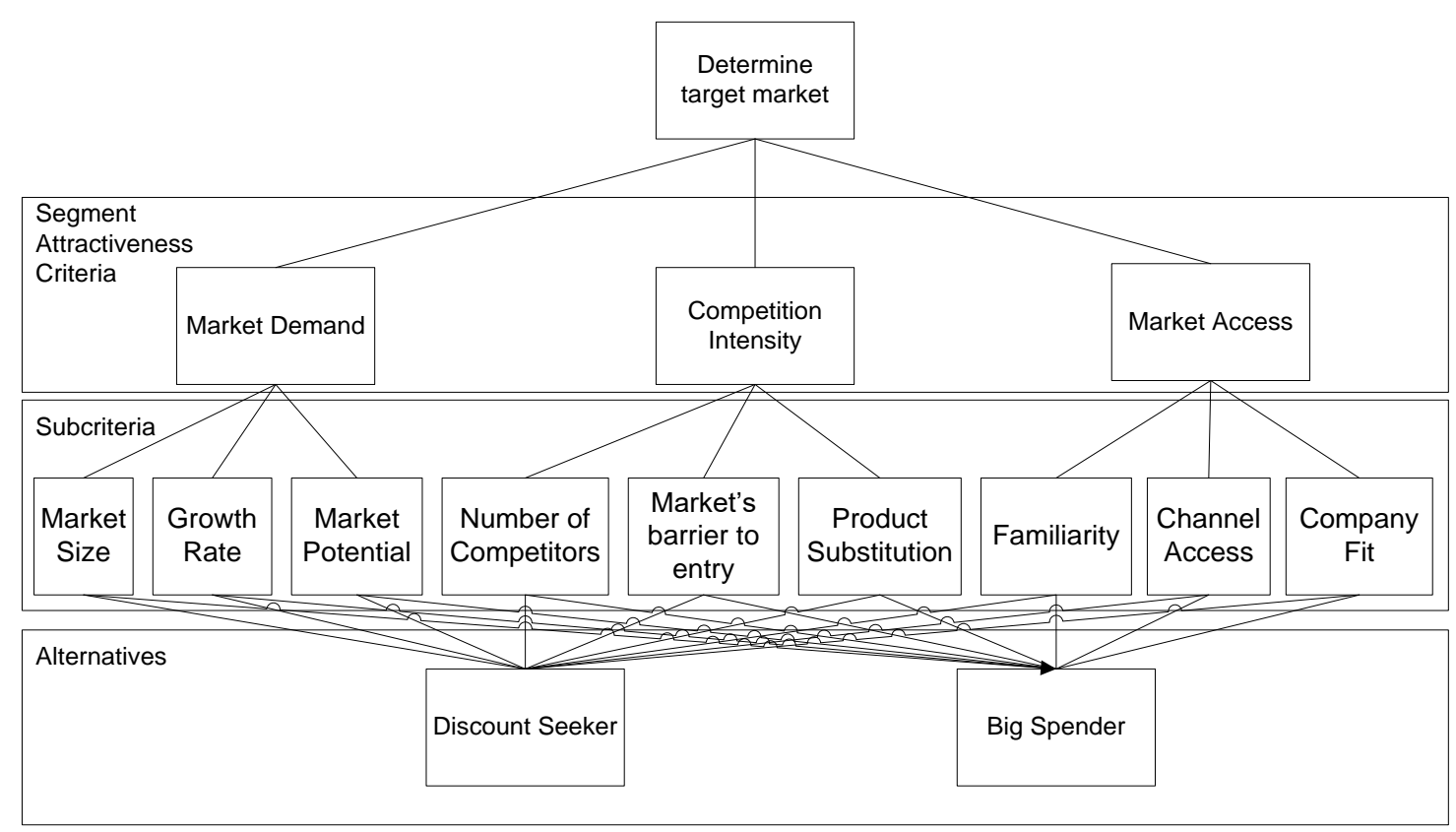

Fig. 1. The Hierarchy Tree

The weight of importance and the evaluation score is calculated based on three experts from companies using the Delphi method. They are Marketing Manager, Advertising and Promotion Manager, and Chief Marketing Officer. The researchers have all worked in the marketing division for nine years. Respondents were asked separately to determine the number of criteria based on their significance. The process is repeated until the findings have been consistent. Priority vector values are first determined as input for the consistency check.

In the meantime, to determine the assessment ranking, the sub-criteria used the same as above but with different questions. Respondents were asked to rate alternative markets or market segments for each criterion. Upon ensuring the accuracy of tests, priority vectors are determined and used as assessment scores for each alternative. The evaluation score for each option is determined by multiplying the evaluation score by weight for each sub-criterion and then multiplying the result by the weighted evaluation criteria for the final rating. After conducting two rounds of interviews and consistency tests AHP, the sub-criteria of market demand is still inconsistent. Therefore, the third round interview only involves the sub-criteria of market demand. The results of the consistency test after the third round of interviews are presented in Table 5 .

Table 5 shows that all the tested criteria are consistent because of CI / RI under 0.1 . Then the importance weight of each rule with an evaluation score on each cluster is calculated using the Delphi method. The result shows that managers give more priority to market demand and market access than competition intensity. It happens probably because "M" focuses more on the quality and innovation of the products offered. In this way, the pressure from the competition can be reduced. Aghdaie and Alimardani [41], In their study, also found that the management of well-known chair manufacturing companies did not view competition as a high priority factor. Table 5 , the highest number is 0,77, which is owned by the Big Spender cluster. Therefore, the Big Spender cluster is the primary target market of "M".

Jang et al. [9] measures travel segment attractiveness based on two criteria. They are market potential and risk. In another study, McQueen and Miller [10] consider segment profitability, accessibility, and variability. Jang, et al. [9] Choose to apply 
profitability, accessibility, and reachability in selecting a target market. All those studies put the same importance to all criteria. This study proves that not all target market selection criteria have the same level of importance.

\begin{tabular}{|c|c|c|c|c|c|c|}
\hline & $\lambda_{\max }$ & $\begin{array}{l}\text { Priority } \\
\text { Vector }\end{array}$ & $\begin{array}{l}\text { Consistency } \\
\text { Index }\end{array}$ & $\mathrm{CI} / \mathrm{RI}$ & $\begin{array}{l}\text { Discount } \\
\text { Seeker }\end{array}$ & $\begin{array}{l}\text { Big } \\
\text { Spender }\end{array}$ \\
\hline Criteria & 3 & & 0 & 0 & & \\
\hline $\begin{array}{l}\text { Market } \\
\text { Demand }\end{array}$ & 3.11 & 0.48 & 0.06 & 0,09 & & \\
\hline - Market size & 3.11 & 0.72 & 0.06 & 0,09 & 0.16 & 0.83 \\
\hline $\begin{array}{l}\text { - Growth } \\
\text { rate }\end{array}$ & 3.11 & 0.20 & 0.06 & 0,09 & 0.83 & 0.16 \\
\hline $\begin{array}{ll}\text { - } & \text { Market } \\
& \text { potential } \\
\end{array}$ & 3.11 & 0.08 & 0.06 & 0,09 & 0.16 & 0.83 \\
\hline $\begin{array}{l}\text { Competition } \\
\text { Intensity }\end{array}$ & 3 & 0.05 & 0 & 0 & & \\
\hline $\begin{array}{l}\text { Number of } \\
\text { competitors }\end{array}$ & 3 & 0.45 & 0 & 0 & 0.13 & 0.87 \\
\hline $\begin{array}{l}\text { Market's } \\
\text { barrier to } \\
\text { entry }\end{array}$ & 3 & 0.10 & 0 & 0 & 0.17 & 0.83 \\
\hline $\begin{array}{ll}\text { - } & \text { Product } \\
\text { substitution }\end{array}$ & 3 & 0.45 & 0 & 0 & 0.17 & 0.83 \\
\hline Market Access & 3 & 0.47 & 0 & 0 & & \\
\hline $\begin{array}{l}\text { Customer } \\
\text { familiarity }\end{array}$ & 3 & 0.14 & 0 & 0 & 0.13 & 0.87 \\
\hline $\begin{array}{l}\text { - Channel } \\
\text { access }\end{array}$ & 3 & 0.14 & 0 & 0 & 0.5 & 0.5 \\
\hline \multirow[t]{2}{*}{$\begin{array}{l}\text { - Company } \\
\text { fit }\end{array}$} & 3 & 0.72 & 0 & 0 & 0.12 & 0.88 \\
\hline & & & $\mathrm{RI}=0.58$ & & 0.23 & 0.77 \\
\hline
\end{tabular}

\subsection{Market Positioning Design}

Data processing shows several characteristics of the target market: (a) Willing to spend more than IDR 300,000 a month to buy clothes; (B) Go to the "M" shop at least three times a year; (c) Focus on fitness and endurance of clothing. Based on the target market's characteristics, especially the third point, the qualitative analysis uses Bull's eye positioning method. The detailed process of determining market position is shown in Fig. 2. The analysis recommends that the "M" market position is: "everlasting quality that fits your body". This position is expected to influence customer perceptions about the product and encourage purchase intentions of the target market. A positive relationship between positioning, customer perception, and plan to buy. It is found in Wang [13].

This study uses a qualitative approach to determine product positioning. Such as the study conducted by Bartikowski, et al. [16]. A quantitative approach can be used, such as Correspondence Analysis [13] and Multidimensional Scaling [14]. Nevertheless, in the end, positioning strategy relies on creativity and ability of the management to catch the gap exist in the market and the mind of customers. Therefore, a good positioning strategy is unique and different from competitors. 


\subsection{Marketing Strategy}

This paper focused on the Big Spender cluster data as the most potential target market. Identification of the marketing mix components that need to be improved is the component that has the lowest average of all questions in each part. Furthermore, these components tested using ANOVA to determine the average difference of each significant component. The results show substantial differences between them, but the promotion has the lowest average score. Therefore, this research will focus on designing the promotion aspect of "M".

Furthermore, a simple survey of 20 respondents used online interviews via Line and WhatsApp and face-to-face meetings with offline shop visitors. The question is, "if "M" wants to provide promotional information to you, what channel do you prefer?" One respondent can mention more than one promotion channel. The result shows that most respondents prefer ads on social media homepage, especially Instagram and Facebook. Therefore, the prototype ads on Facebook and Instagram were designed. The design of the promotion strategy must undoubtedly follow the market position that has been created, namely "everlasting quality that fits your body ". The market position provides the idea of choosing brand ambassadors from several celebrities with diverse body shapes. In this way, customers perceive that "M" products are suitable for various body shapes. Moreover, the previous study shows that celebrity endorser significantly influences the intention to buy [23].

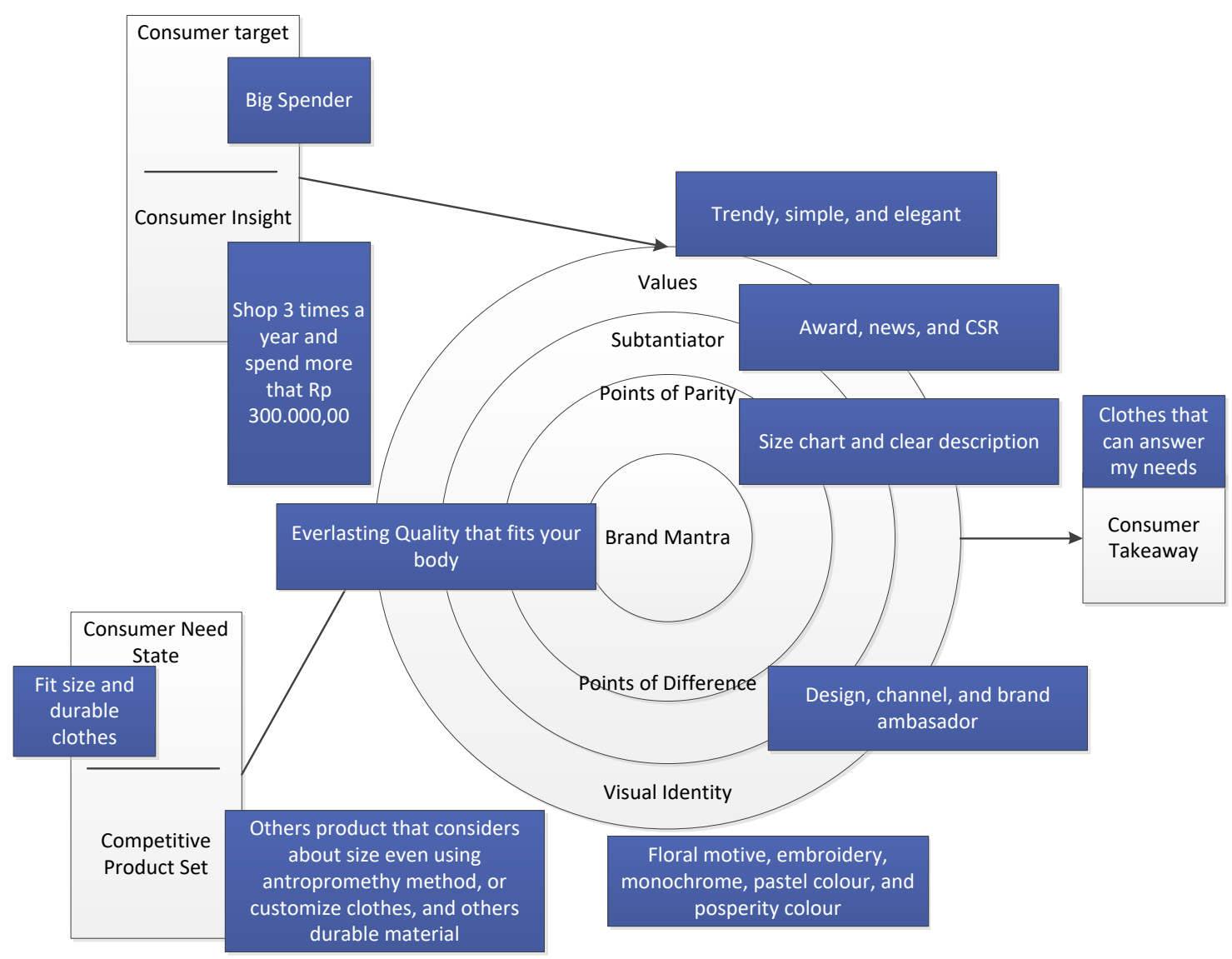

Fig. 2. Bull's Eye Positioning Analysis for "M" 
Ads designed for Instagram and Facebook are the same. A prototype sample is in the Appendix. Then, the groups consist of 20 women who have an interest in fashion and are actively using Instagram and Facebook. One group is a control group, and the other is a stimuli group. The control group is presented with an "M" ad at this time. Another group is presented with a prototype ad. Each group was asked their opinion about each ad. Their ideas are translated into a nominal scale and tested in a non-parametric test. It shows that the new design is better than the existing design because the $p$-value of current and prototype ads was $0.04(<0.05)$. This result is different from a study conducted by Halliwell and Dittmar [42]. They found that the model's body size displayed in the advertisement and did not affect the respondent's evaluation. However, it increases body-focused anxiety. Moreover, Halliwell and Dittmar [42] advise advertisers to use models with average or even large body sizes to avoid body-focused anxiety among the viewers.

\section{Conclusion}

Customers "M" was split into two categories, the Big Spender and the Discount Seeker. The results of the Delphi and AHP approaches have led the organization to focus on market demand and market access. Therefore, the Big Spender cluster is chosen as the target market. The correct market position for this class is "eternal quality that suits your body," highlighting the size and durability of your clothes. More review of this cluster reveals that the marketing portion is a combination. It has the lowest average of all promotional strategy problems. Most respondents prefer social media homepage ads, particularly Instagram and Facebook. Next, Facebook and Instagram ads are planned for home prototypes. A simple survey of 20 respondents reveals that the new design is better than the existing one. This study proposes a marketing strategy that is appropriate for the current market. The goal of Companies is advised to regularly analyze the suitability of strategy and customers to ensure the effectiveness of their marketing strategies. Future research may review aspects of social media ads that attract the attention of viewers. In this way, the ads attract the viewer's attention despite the many other ads accepted.

\section{Acknowledgment}

The authors thank the editor and anonymous reviewers for their valuable input to this paper.

\section{References}

[1] J. B. Smith and M. Colgate, "Customer value creation: a practical framework," Journal of marketing Theory Practice, vol. 15, pp. 7-23, 2007. https://doi.org/10.2753/MTP1069-6679150101.

[2] Y. Hong, X. Zeng, X. Cao, Y. Chen, Y. Chen, and Z. Pan, "A framework of consumer perceived value on fashion products for female college students of France," $D E$ REDACTIE, p. 495, 2018.

[3] T. Pevec and A. Pisnik, "Empirical evaluation of a conceptual model for the perceived value of health services," Slovenian Journal of Public Health, vol. 57, pp. 175-182, 2018. https://doi.org/10.2478/sjph-2018-0022.

[4] K.-P. Wiedmann, S. Behrens, C. Klarmann, and N. Hennigs, "Customer value perception: cross-generational preferences for wine," British Food Journal, vol. 116, pp. 1128-1142, 2014. https://doi.org/10.1108/BFJ-01-2013-0027.

[5] H. S. Yu, J. J. Zhang, D. H. Kim, K. K. Chen, C. Henderson, S. D. Min, et al., "Service quality, perceived value, customer satisfaction, and behavioral intention among 
fitness center members aged 60 years and over," Social Behavior Personality: an international journal, vol. 42, pp. 757-767, 2014. https://doi.org/10.2224/sbp.2014.42.5.757.

[6] N. A. Morgan, K. A. Whitler, H. Feng, and S. Chari, "Research in marketing strategy," Journal of the Academy of Marketing Science, vol. 47, pp. 4-29, 2019. https://doi.org/10.1007/s11747-018-0598-1.

[7] M. Z. Abiddin, I. Masudin, and D. M. Utama, "Pemilihan Strategi Pemasaran Dengan Metode SWOT Dan TOPSIS," Jurnal Teknik Industri, vol. 18, pp. 55-67, 2017. https://doi.org/10.22219/JTIUMM.Vol18.No1.55-67.

[8] A. A. Robbika and T. Baroto, "Perencanaan Strategi Pemasaran Dengan Metode Multidimensional Scalling Dan Quality Function Deployment," Jurnal Teknik Industri, vol. 17, pp. 12-21, 2016. https://doi.org/10.22219/JTIUMM.Vol17.No1.1221.

[9] S. Jang, A. M. Morrison, and J. T. O'leary, "A procedure for target market selection in tourism," Journal of Travel Tourism Marketing, vol. 16, pp. 19-33, 2004. https://doi.org/10.1300/J073v16n01_03.

[10] J. McQueen and K. E. Miller, "Target market selection of tourists: A comparison of approaches," Journal of Travel Research, vol. 24, pp. 2-6, 1985. https://doi.org/10.1177/004728758502400101.

[11] R. R. Perdue, "Target market selection and marketing strategy: The Colorado downhill skiing industry," Journal of Travel Research, vol. 34, pp. 39-46, 1996. https://doi.org/10.1177/004728759603400406.

[12] C. H. Koch and R. I. Gyrd-Jones, "Corporate brand positioning in complex industrial firms: Introducing a dynamic, process approach to positioning," Industrial Marketing Management, 2019. https://doi.org/10.1016/j.indmarman.2019.03.011.

[13] C.-H. Wang, "A market-oriented approach to accomplish product positioning and product recommendation for smart phones and wearable devices," International Journal of Production Research, vol. 53, pp. 2542-2553, 2015. https://doi.org/10.1080/00207543.2014.991046.

[14] H. J. Chang and T.-M. Jai, "Is fast fashion sustainable? The effect of positioning strategies on consumers' attitudes and purchase intentions," Social Responsibility Journal, vol. 11, pp. 853-867, 2015. https://doi.org/10.1108/SRJ-07-2014-0095.

[15] S. Panda, A. K. Paswan, and S. P. Mishra, "Impact of positioning strategies on franchise fee structure," Industrial Marketing Management, 2018. https://doi.org/10.1016/j.indmarman.2018.10.001.

[16] B. Bartikowski, F. Fastoso, and H. Gierl, "Luxury cars Made-in-China: Consequences for brand positioning," Journal of Business Research, 2019. https://doi.org/10.1016/j.jbusres.2019.01.072.

[17] C. E. Gengler and M. S. Mulvey, "Planning pre-launch positioning: Segmentation via willingness-to-pay and means-end brand differentiators," Journal of Brand Management, vol. 24, pp. 230-249, 2017. https://doi.org/10.1057/s41262-017-0030-z.

[18] M. Bouzon, K. Govindan, C. M. T. Rodriguez, and L. M. Campos, "Identification and analysis of reverse logistics barriers using fuzzy Delphi method and AHP," Resources, Conservation Recycling, vol. 108, pp. 182-197, 2016. https://doi.org/10.1016/j.resconrec.2015.05.021.

[19] S. A. Delbari, S. I. Ng, Y. A. Aziz, and J. A. Ho, "An investigation of key competitiveness indicators and drivers of full-service airlines using Delphi and AHP techniques," Journal of Air Transport Management, vol. 52, pp. 23-34, 2016. https://doi.org/10.1016/j.jairtraman.2015.12.004. 
[20] C. Ashley and T. Tuten, "Creative strategies in social media marketing: An exploratory study of branded social content and consumer engagement," Psychology Marketing, vol. 32, pp. 15-27, 2015. https://doi.org/10.1002/mar.20761.

[21] Y.-T. Chang, H. Yu, and H.-P. Lu, "Persuasive messages, popularity cohesion, and message diffusion in social media marketing," Journal of Business Research, vol. 68, pp. 777-782, 2015. https://doi.org/10.1016/j.jbusres.2014.11.027.

[22] B. Godey, A. Manthiou, D. Pederzoli, J. Rokka, G. Aiello, R. Donvito, et al., "Social media marketing efforts of luxury brands: Influence on brand equity and consumer behavior," Journal of business research, vol. 69, pp. 5833-5841, 2016. https://doi.org/10.1016/j.jbusres.2016.04.181.

[23] F. Sharon, L. Meilinda, S. Wijaya, and V. Iskandar, "Pengaruh Karakteristik Celebrity Endorser Melalui Media Sosial Instagram Terhadap Minat Beli Konsumen Pada Restoran Dan Café Di Surabaya," Jurnal Hospitality dan Manajemen Jasa, vol. $\quad 6,2018 . \quad$ http://publication.petra.ac.id/index.php/manajemenperhotelan/article/view/7504.

[24] J. Ninan, S. Clegg, and A. Mahalingam, "Branding and governmentality for infrastructure megaprojects: The role of social media," International Journal of $\begin{array}{llllll}\text { Project } & \text { Management, } & \text { vol. } & 37, & \text { pp. } & \text { 59-72, }\end{array}$ https://doi.org/10.1016/j.ijproman.2018.10.005.

[25] H. R. Bernard and H. R. Bernard, Social research methods: Qualitative and quantitative approaches: Sage, 2013.

[26] J. Jaskulska, "Quality of service and product as the main factors influencing customers' satisfaction in the clothing retailing industry in Ireland-case study of Zara Plc," Dublin Business School, 2013. http://hdl.handle.net/10788/1713.

[27] R. R. R. Gundala, "Retail store image: a study of the Cyprus clothing industry," International Journal of Management Marketing Research, vol. 3, pp. 67-81, 2010. https://ssrn.com/abstract=1880203.

[28] M. H. M. Javadi, H. R. Dolatabadi, M. Nourbakhsh, A. Poursaeedi, and A. R. Asadollahi, "An analysis of factors affecting on online shopping behavior of consumers," International Journal of Marketing Studies, vol. 4, p. 81, 2012. http://doi.org/10.5539/ijms.v4n5p81.

[29] M. K. Yee, C. H. Khoo, S. Y. Kuit, C. S. Lee, and Y. S. Tan, "Customers' perceptions of the marketing mix and the effect on Malaysian hypermarkets' brand loyalty," UTAR, 2011.

[30] J. Andreti, N. H. Zhafira, S. S. Akmal, and S. Kumar, "The analysis of product, price, place, promotion and service quality on customers' buying decision of Convenience Store: A survey of young adult in Bekasi, West Java, Indonesia," International Journal of Advances in Management Economics, vol. 2, pp. 72-78, 2013. http://www.managementjournal.info/index.php/IJAME/article/view/332.

[31] S. B. Green, "How many subjects does it take to do a regression analysis," Multivariate behavioral research, vol. 26, pp. 499-510, 1991. https://doi.org/10.1207/s15327906mbr2603_7.

[32] J. Hair Jnr, W. Black, B. Babin, and R. Anderson, "Multivariate data analysis: a global perspective," ed: Upper Saddle River: Prentice Hall, 2010.

[33] T. L. Saaty, "How to make a decision: the analytic hierarchy process," European journal of operational research, vol. 48, pp. 9-26, 1990. https://doi.org/10.1016/03772217(90)90057-I.

[34] X. Wu, "Stakeholder identifying and positioning (SIP) models: From Google's operation in China to a general case-analysis framework," Public Relations Review, vol. 33, pp. 415-425, 2007. https://doi.org/10.1016/j.pubrev.2007.08.016. 
[35] D. Yankelovich and D. Meer, Rediscovering market segmentation vol. 84, 2006.

[36] R. J. Best, "Market-based management: Strategies for growing customer value and profitability," 2009.

[37] W. P. Barnett, "The dynamics of competitive intensity," Administrative Science Quarterly, pp. 128-160, 1997. https://doi.org/10.2307/2393811.

[38] F. Karakaya and M. J. Stahl, "Barriers to entry and market entry decisions in consumer and industrial goods markets," Journal of marketing, vol. 53, pp. 80-91, 1989. https://doi.org/10.1177/002224298905300206.

[39] J. I. Bulow, J. D. Geanakoplos, and P. D. Klemperer, "Multimarket oligopoly: Strategic substitutes and complements," Journal of Political economy, vol. 93, pp. 488-511, 1985. https://doi.org/10.1086/261312.

[40] S. Askool and K. Nakata, "A conceptual model for acceptance of social CRM systems based on a scoping study," Ai \& Society, vol. 26, pp. 205-220, 2011. https://doi.org/10.1007/s00146-010-0311-5.

[41] M. H. Aghdaie and M. Alimardani, "Target market selection based on market segment evaluation: a multiple attribute decision making approach," International Journal of Operational Research, vol. 24, pp. 262-278, 2015. https://doi.org/10.1504/IJOR.2015.072231.

[42] E. Halliwell and H. Dittmar, "Does size matter? The impact of model's body size on women's body-focused anxiety and advertising effectiveness," Journal of Social

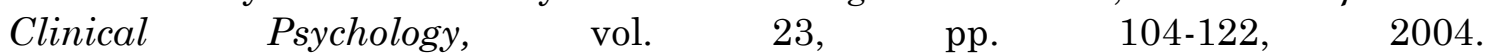
https://doi.org/10.1521/jscp.23.1.104.26989.

Appendix
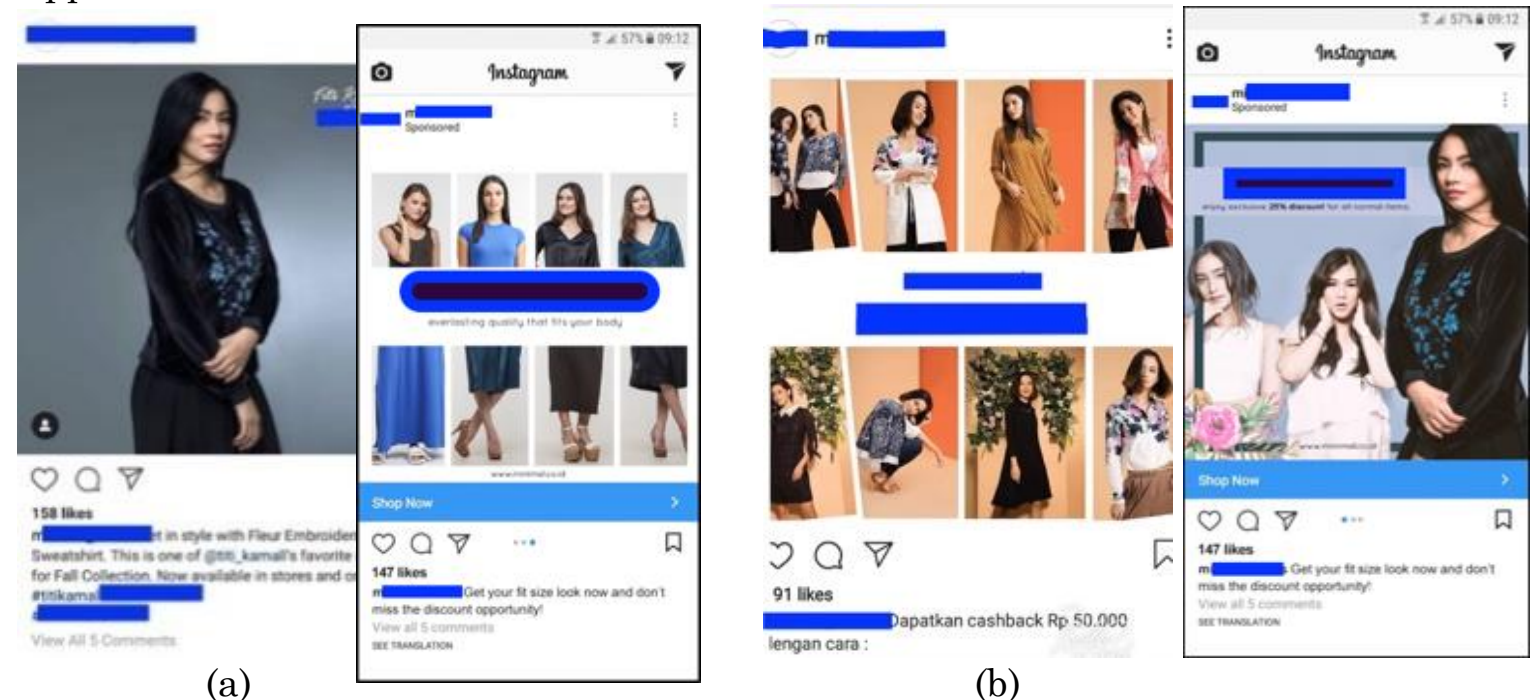

(b)

The Stimulus: (a) Control; (b) Prototype 